\title{
Four New Metal Complexes with the Amino Acid Deoxyalliin
}

\author{
Antonio C. Massabni ${ }^{*}, a$, Pedro P. Corbi ${ }^{a}$, Petr Melnikov ${ }^{b}$, Marisa A. Zacharias ${ }^{c}$ \\ and Hercílio R. Rechenberg ${ }^{d}$
}

${ }^{a}$ Instituto de Química, Universidade Estadual Paulista, Rua Prof. Francisco Degni s/n, CP 355, 14801-970 Araraquara - SP, Brazil

${ }^{b}$ CCET, Universidade Federal do Mato Grosso do Sul, Cidade Universitária s/n, 79070-900 Campo Grande - MS, Brazil

${ }^{c}$ Instituto Nacional de Pesquisas Espaciais, 12630-000 Cachoeira Paulista - SP, Brazil

${ }^{d}$ Instituto de Física, Universidade de São Paulo, Rua do Matão, Travessa R, 187, Cidade Universitária, 05508-900 São Paulo - SP, Brazil

Os complexos sólidos $\left[\mathrm{Co}\left(\mathrm{C}_{6} \mathrm{H}_{10} \mathrm{NO}_{2} \mathrm{~S}\right)_{2}\right],\left[\mathrm{Ni}\left(\mathrm{C}_{6} \mathrm{H}_{10} \mathrm{NO}_{2} \mathrm{~S}\right)_{2}\right],\left[\mathrm{Cu}\left(\mathrm{C}_{6} \mathrm{H}_{10} \mathrm{NO}_{2} \mathrm{~S}\right)_{2}\right]$ e $\left[\mathrm{Fe}\left(\mathrm{C}_{6} \mathrm{H}_{10} \mathrm{NO}_{2} \mathrm{~S}\right)_{2}\right]$ foram obtidos pela reação dos sais de cobalto(II), níquel(II), cobre(II) e ferro(II) com o sal de potássio da desoxialiina (S-alil-L-cisteína). Os espectros eletrônicos de absorção são típicos de estruturas octaédricas. A espectroscopia no infravermelho confirma a coordenação do ligante aos íons metálicos através dos grupos $\left(\mathrm{COO}^{-}\right)$e $\left(\mathrm{NH}_{2}\right)$. O espectro de EPR do complexo de cobre(II) indica uma ligeira distorsão de sua simetria octaédrica. Os parâmetros obtidos por espectroscopia Mössbauer permitiram identificar a presença dos íons ferro(II) e ferro(III) na mesma amostra, ambos em geometria octaédrica. A decomposição térmica dos complexos resultou na formação de $\mathrm{CoO}, \mathrm{NiO}, \mathrm{CuO}$ e $\mathrm{Fe}_{2} \mathrm{O}_{3}$ como produtos finais. Os compostos apresentam baixa solubilidade em água e em solventes orgânicos usuais.

The solid complexes $\left[\mathrm{Co}\left(\mathrm{C}_{6} \mathrm{H}_{10} \mathrm{NO}_{2} \mathrm{~S}\right)_{2}\right],\left[\mathrm{Ni}_{(}\left(\mathrm{C}_{6} \mathrm{H}_{10} \mathrm{NO}_{2} \mathrm{~S}\right)_{2}\right],\left[\mathrm{Cu}\left(\mathrm{C}_{6} \mathrm{H}_{10} \mathrm{NO}_{2} \mathrm{~S}\right)_{2}\right]$ and $\left[\mathrm{Fe}\left(\mathrm{C}_{6} \mathrm{H}_{10} \mathrm{NO}_{2} \mathrm{~S}\right)_{2}\right]$ were obtained from the reaction of cobalt(II), nickel(II), copper(II) and iron(II) salts with the potassium salt of the amino acid deoxyalliin (S-allyl-L-cysteine). Electronic absorption spectra of the complexes are typical of octahedral structures. Infrared spectroscopy confirms the ligand coordination to the metal ions through $\left(\mathrm{COO}^{-}\right)$and $\left(\mathrm{NH}_{2}\right)$ groups. EPR spectrum of the $\mathrm{Cu}$ (II) complex indicates a slight distortion of its octahedral symmetry. Mössbauer parameters permitted to identify the presence of iron(II) and iron(III) species in the same sample, both of octahedral geometry. Thermal decomposition of the complexes lead to the formation of $\mathrm{CoO}, \mathrm{NiO}$, $\mathrm{CuO}$ and $\mathrm{Fe}_{2} \mathrm{O}_{3}$ as final products. The compounds show poor solubility in water and in the common organic solvents.

Keywords: deoxyalliin, cobalt, nickel, copper, iron

\section{Introduction}

Deoxyalliin (S-allyl-L-cysteine, $\mathrm{C}_{6} \mathrm{H}_{11} \mathrm{NO}_{2} \mathrm{~S}$, Figure 1), a product of vegetal origin, is an amino acid derivative from cysteine. It is present in onion and garlic bulbs. ${ }^{1,2}$<smiles>C=CCSCC(N)C(=O)O</smiles>

Figure 1. Schematic structure of deoxyalliin.

*e-mail: massabni@iq.unesp.br
Recent studies have shown that deoxyalliin may be considered a biological antagonist of nitrosomorpholine, substance that was once reported as being responsible for the development of hepatic cancer in humans. ${ }^{3}$ It also exhibits capacity of inhibiting the proliferation of malignant cells in human nervous system and thorax. ${ }^{4,5}$ Deoxyalliin showed, after its oral dosage in rats, mice and dogs, a fast absorption by the gastrointestinal system, being distributed mainly among blood plasma, liver and kidney. Its excretion occurs through the urine in the form of $\mathrm{N}$-acetylcysteine or even as S-allylcysteine. ${ }^{6}$

In view of its biological and chemical properties, deoxyalliin is a suitable ligand for the synthesis of complexes involving bioactive metals as cobalt, nickel, 
copper and iron. Drugs like deoxyalliin could act in controlling the concentration of the metal ions in the body by complex formation without causing collateral effects. The present work is dedicated to the synthesis and characterization of four new metal complexes with deoxyalliin.

\section{Experimental}

\section{Materials and methods}

L-Deoxyalliin was purchased from LKT laboratories, analytical grade purity, while cobalt(II), nickel(II) and copper(II) chlorides were purchased from Acros and Merck Laboratories, analytical grade purity. Iron(II) sulfate was purchased from Merck laboratories. Elemental analyses were performed using a CHNS-O EA1110 Analyzer, CE Instruments; pure cystine was used as a reference substance. Cobalt, nickel, copper and iron contents were determined by using the atomic absorption technique with a Perkin Elmer AAnalyst 300. Infrared spectra were recorded on a FT-IR Spectrophotometer Spectrum 2000, Perkin Elmer; samples were prepared in $\mathrm{KBr}$ and CsI pellets. Electronic absorption spectra for cobalt and nickel complexes in aqueous solution were measured on a Cary $5 \mathrm{G}$ Spectrophotometer while the iron complex spectrum was obtained on a Perkin Elmer Lambda14P spectrophotometer. The copper(II) complex spectrum was measured by diffusion reflectance of the solid sample by using a Hewlett Packard 8453 Spectrophotometer. Thermal analyses were performed on a Thermoanalyzer TG/DTA simultaneous SDT 2960 TA Instruments, in the following conditions: synthetic air, $100 \mathrm{~cm}^{3} \mathrm{~min}^{-1}$ and heating rate of $10{ }^{\circ} \mathrm{C} \mathrm{min}{ }^{-1}$, from $40{ }^{\circ} \mathrm{C}$ to $1100{ }^{\circ} \mathrm{C}$. Magnetic susceptibilities of the $\mathrm{Co}$ (II), $\mathrm{Ni}$ (II) and $\mathrm{Cu}$ (II) complexes were determined by using a Gouy balance at room temperature. EPR spectrum of the $\mathrm{Cu}$ (II) complex was measured at frequency of $9.45 \mathrm{GHz}$ using a Brucker ESP $300 \mathrm{E}$ electron spin resonance. The spectrum was recorded at 77K. Mössbauer spectroscopy of the Fe(II) complex was performed in a constant-acceleration spectrometer using a ${ }^{57} \mathrm{Co}(\mathrm{Rh})$ source. Both source and absorber were kept at room temperature. A metallic iron foil was used for velocity calibration and as an isomer shift reference.

\section{Preparation of the complexes}

The $\mathrm{Co}(\mathrm{II}), \mathrm{Ni}(\mathrm{II})$ and $\mathrm{Cu}(\mathrm{II})$ complexes were synthesized by adding $7.5 \times 10^{-4} \mathrm{~mol}$ of the respective metal chloride, in aqueous solution at $\mathrm{pH}$ 5.0, to an aqueous solution of the potassium salt of deoxyalliin previously prepared, containing $1.5 \times 10^{-3} \mathrm{~mol}$ of the ligand (molar proportion metal : ligand of 1:2) at $\mathrm{pH}$ 9.0. These reactions were carried out at room temperature under stirring. Changes in the colour of the respective solution show that the nickel(II) and cobalt(II) complexes were immediately formed and after a few minutes of stirring the complexes precipitated as blue and rose solids, respectively. The copper(II) complex precipitated immediately as a blue solid. The complexes were filtered, washed with ethanol and left for two days in a desiccator under $\mathrm{P}_{4} \mathrm{O}_{10}$. Final yields of the syntheses of the $\mathrm{Co}(\mathrm{II}), \mathrm{Ni}$ (II) and $\mathrm{Cu}$ (II) complexes were $73 \%, 56 \%$ and $71 \%$, respectively. No single crystals of the complexes were obtained to perform an X-ray structure determination, even after several attempts.

The iron complex was prepared by the reaction of an aqueous solution containing $2.0 \times 10^{-3} \mathrm{~mol}$ of iron(II) sulfate at $\mathrm{pH} 4.5$ with an aqueous solution containing $4.0 \times 10^{-3}$ mol of the potassium salt of the amino acid at $\mathrm{pH} 10.0$ under stirring. The reaction was carried out under nitrogen atmosphere. The solid complex was obtained after few minutes of constant stirring of the dark green solution. The solid complex was filtered under nitrogen atmosphere, washed with water and absolute ethanol, dried over vacuum and stored in Schlenk flasks.

\section{Chemical analyses values}

Anal. Calc. for $\left[\mathrm{Co}\left(\mathrm{C}_{6} \mathrm{H}_{10} \mathrm{NO}_{2} \mathrm{~S}\right)_{2}\right] \mathrm{C}, 38.0 ; \mathrm{H}, 5.31 ; \mathrm{N}$, 7.38; S, 16.9; Co, 15.5. Found: C, 38.1; H, 5.89; N, 7.35; S, 16.0; Co, 15.5\%. Anal. Calc. for $\left[\mathrm{Ni}\left(\mathrm{C}_{6} \mathrm{H}_{10} \mathrm{NO}_{2} \mathrm{~S}\right)_{2}\right] \mathrm{C}, 38.0$; H, 5.32; N, 7.39; S, 16.9; Ni, 15.5. Found: C, 37.7; H, 5.95; $\mathrm{N}, 7.26 ; \mathrm{S}, 17.5 ; \mathrm{Ni}, 15.1 \%$. Anal. Calc. for $\left[\mathrm{Cu}\left(\mathrm{C}_{6} \mathrm{H}_{10} \mathrm{NO}_{2} \mathrm{~S}\right)_{2}\right]$ C, 37.5; H, 5.26; N, 7.30; S, 16.7; Cu, 16.6. Found: C, 37.5; H, 5.30; N, 7.30; S, 16.9; Cu, 16.3\%. Anal. Calc. for $\left[\mathrm{Fe}\left(\mathrm{C}_{6} \mathrm{H}_{10} \mathrm{NO}_{2} \mathrm{~S}\right)_{2}\right] \mathrm{C}, 38.1 ; \mathrm{H}, 5.33 ; \mathrm{N}, 7.40 ; \mathrm{Fe}, 14.8$. Found: C, 36.9; H, 5.23; N, 7.20; Fe, 14.5\%.

\section{Results and Discussion}

\section{Electronic absorption spectroscopy}

The electronic absorption spectroscopy data for Co(II), $\mathrm{Ni}(\mathrm{II}), \mathrm{Cu}(\mathrm{II})$ and $\mathrm{Fe}(\mathrm{II})$ complexes with deoxyalliin are given in Table 1

The positions of the band maxima and the respective assignments for $\mathrm{Co}(\mathrm{II})$ and $\mathrm{Ni}$ (II) complexes with deoxyalliin are typical of octahedral geometries. Molar extinction coefficients ( $\xi$ ) for $\mathrm{Co}(\mathrm{II})$ and $\mathrm{Ni}$ (II) complexes are also presented in Table 1. The calculated $10 \mathrm{Dq}$ and B 
Table 1. Electronic absorption spectra of $\mathrm{Co}(\mathrm{II}), \mathrm{Ni}(\mathrm{II}), \mathrm{Cu}(\mathrm{II})$ and $\mathrm{Fe}(\mathrm{II})$ complexes with deoxyalliin

\begin{tabular}{|c|c|c|c|}
\hline Compound & Band position $(\mathrm{nm})$ & Assignment & $\xi$ values $\left(\mathrm{L} \mathrm{mol}^{-1} \mathrm{~cm}^{-1}\right)$ \\
\hline$\left[\mathrm{Co}\left(\mathrm{C}_{6} \mathrm{H}_{10} \mathrm{NO}_{2} \mathrm{~S}\right)_{2}\right]$ & $\begin{array}{c}490 \\
1130\end{array}$ & $\begin{array}{c}{ }^{4} \mathrm{~T}_{1 \mathrm{~g}}(\mathrm{P}) \leftarrow{ }^{4} \mathrm{~T}_{1 \mathrm{~g}} \\
{ }^{4} \mathrm{~T}_{2 \mathrm{~g}} \leftarrow{ }^{4} \mathrm{~T}_{1 \mathrm{~g}}\end{array}$ & $\begin{array}{c}18 \\
6\end{array}$ \\
\hline$\left[\mathrm{Ni}\left(\mathrm{C}_{6} \mathrm{H}_{10} \mathrm{NO}_{2} \mathrm{~S}\right)_{2}\right]$ & $\begin{array}{c}366 \\
620 \\
736 \text { (shoulder) } \\
1017 \\
\end{array}$ & $\begin{array}{c}{ }^{3} \mathrm{~T}_{1 \mathrm{~g}}(\mathrm{P}) \leftarrow{ }^{3} \mathrm{~A}_{2 \mathrm{~g}} \\
{ }^{3} \mathrm{~T}_{1 \mathrm{~g}} \leftarrow{ }^{3} \mathrm{~A}_{2 \mathrm{~g}} \\
{ }^{1} \mathrm{E}_{\mathrm{g}} \leftarrow{ }^{3} \mathrm{~A}_{2 \mathrm{~g}} \\
{ }^{3} \mathrm{~T}_{2 \mathrm{~g}} \leftarrow{ }^{3} \mathrm{~A}_{2 \mathrm{~g}}\end{array}$ & $\begin{array}{c}24 \\
12 \\
- \\
15 \\
\end{array}$ \\
\hline$\left[\mathrm{Cu}\left(\mathrm{C}_{6} \mathrm{H}_{10} \mathrm{NO}_{2} \mathrm{~S}\right)_{2}\right]$ & 619 & $\mathrm{~d}_{\mathrm{x} 2-\mathrm{y} 2} \leftarrow \mathrm{d}_{\mathrm{xy}{ }^{\prime} \mathrm{xz}{ }^{\prime} \mathrm{yz}}$ & - \\
\hline$\left[\mathrm{Fe}\left(\mathrm{C}_{6} \mathrm{H}_{10} \mathrm{NO}_{2} \mathrm{~S}\right)_{2}\right]$ & $\begin{array}{c}640 \\
800-900 \text { (shoulder) }\end{array}$ & $\begin{array}{l}{ }^{5} \mathrm{~A}_{1 \mathrm{~g}} \leftarrow{ }^{5} \mathrm{~T}_{2 \mathrm{~g}} \\
{ }^{5} \mathrm{~B}_{1 \mathrm{~g}} \leftarrow{ }^{5} \mathrm{~T}_{2 \mathrm{~g}}\end{array}$ & - \\
\hline
\end{tabular}

values for $\mathrm{Co}$ (II) complex are equal to $11.0 \times 10^{3} \mathrm{~cm}^{-1}$ and $920 \mathrm{~cm}^{-1}$, respectively. ${ }^{7}$ For Ni(II) complex the $10 \mathrm{Dq}$ and B values are $9.83 \times 10^{3} \mathrm{~cm}^{-1}$ and $923 \mathrm{~cm}^{-1}$, respectively, being similar to those obtained for the octahedral $\mathrm{Ni}(\mathrm{II})$ complexes of the amino acids methionine, methionine sulfoxide and S,S'-methylenebis(cysteine), ligands which are structurally related to deoxyalliin..$^{8-10}$ It is important to stand out that for the $\mathrm{Co}(\mathrm{II})$ and $\mathrm{Ni}(\mathrm{II})$ complexes, the electronic absorption spectra in aqueous solution were obtained immediately after the ligand and the metal salt were mixed, in order to avoid precipitation of the complex.

The electronic absorption spectrum of a solid sample of the copper(II) complex exhibits a broad band with a maximum at $619 \mathrm{~nm}$ which can be assigned to hexacoordinated species of $\mathrm{Cu}(\mathrm{II})$, as it occurs for $\mathrm{K}_{2} \mathrm{PbCu}\left(\mathrm{NO}_{2}\right)_{6}$, where $\mathrm{Cu}$ (II) is in a distorted octahedral arrangement due to the Jahn Teller effect. ${ }^{11}$

The electronic absorption spectrum of the iron(II) complex is characteristic of an octahedral geometry with a high spin electronic $\mathrm{d}^{6}$ configuration. According to this electronic distribution, only one well-defined transition ${ }^{5} \mathrm{E}_{\mathrm{g}} \leftarrow{ }^{5} \mathrm{~T}_{2 \mathrm{~g}}$ was expected. However, due to the Jahn Teller effect, the ${ }^{5} \mathrm{E}_{\mathrm{g}}$ term is split in two terms ${ }^{5} \mathrm{~A}_{1}$ and ${ }^{5} \mathrm{~B}_{1}$, which are responsible for the occurrence of a band and a shoulder in the spectrum. ${ }^{7}$ In order to avoid precipitation and an oxidative process, the electronic absorption spectrum of iron(II) complex was also obtained immediately after the reaction of the ligand and the metal salt. The solid complex is readily oxidized by air with its color changing from pale green to brown.

\section{Infrared spectroscopy}

As it was postulated, for amino acids, the difference between the vibrational frequencies $v_{\text {asym }}\left(\mathrm{COO}^{-}\right)$and $v_{\text {sym }}$ $\left(\mathrm{COO}^{-}\right), \Delta$, generally increase when the $\mathrm{M}-\mathrm{O}$ bond strength increases, depending on the carboxylate coordination, which can be monodentade or bidentade. ${ }^{12}$ The monodentade coordination gives rise to higher $\Delta$ values while the bidentade leads to $\Delta$ values closer to those found for ionic carboxylate compounds, as, for instance, for the potassium amino acid salts. The vibrational frequencies related to $v_{\text {as }}$ $\left(\mathrm{COO}^{-}\right)$and $v_{\mathrm{s}}\left(\mathrm{COO}^{-}\right)$in potassium S-allyl-L-cysteinate occur at 1575 and $1404 \mathrm{~cm}^{-1}$, while for the cobalt and nickel complexes they are observed at 1592 and $1409 \mathrm{~cm}^{-1}$, respectively. So, for potassium S-allyl-L-cysteinate $\Delta=171$ $\mathrm{cm}^{-1}$ and for the cobalt and nickel complexes $\Delta=183 \mathrm{~cm}^{-1}$. For iron(II) and copper(II) complexes $\Delta=193 \mathrm{~cm}^{-1}$ and 229 $\mathrm{cm}^{-1}$, respectively. These values are an indication that both oxygen atoms of the $\mathrm{COO}^{-}$group are involved in coordination to the metal ions, as it occurs for polymeric metal complexes with methionine and S,S'methylenebis(cysteine). ${ }^{8,10-13}$ For such complexes, it was proposed that each $\left(\mathrm{COO}^{-}\right)$is coordinated to two metal ions as a bidentade-bridging group, forming a polymeric structure.

Two very well resolved bands at 3450 and $3280 \mathrm{~cm}^{-1}$ are an indication of coordination of the amino group to the metal ions..$^{12}$ In the infrared spectrum of potassium Sallyl-L-cysteinate, the broad band at $3350-2575 \mathrm{~cm}^{-1}$ corresponds to the $\mathrm{NH}_{2}$ frequencies, while in the spectrum of deoxyalliin the frequencies related to the amino group are observed in the range $3160-2675 \mathrm{~cm}^{-1}$ (broad band). The amino group involvement in the coordination is attested by the presence of two well-resolved bands at 3335 and $3278 \mathrm{~cm}^{-1}$ for the Co(II) complex, at 3359 and 3276 $\mathrm{cm}^{-1}$ for the $\mathrm{Ni}$ (II) complex, at 3281 and $3234 \mathrm{~cm}^{-1}$ for the $\mathrm{Cu}$ (II) complex and at 3333 and $3280 \mathrm{~cm}^{-1}$ for iron complex. The absence of a band at $2050-2150 \mathrm{~cm}^{-1}$ in the spectra of the complexes, in comparison to the free ligand and its potassium salt, confirms the coordination through the amino group..$^{14}$ The absence of the $\delta_{a s}\left(\mathrm{NH}_{3}{ }^{+}\right)$vibration in the spectra of the complexes also constitutes another valuable proof of the involvement of the $\mathrm{NH}_{2}$ group coordination. The $\delta_{\text {as }}\left(\mathrm{NH}_{3}^{+}\right)$vibration of the free ligand appears at $1505 \mathrm{~cm}^{-1}$. 
Infrared spectra of the complexes were also measured in the region $150-700 \mathrm{~cm}^{-1}$ in order to identify frequencies related to $\mathrm{M}-\mathrm{O}$ and $\mathrm{M}-\mathrm{N}$ bonds. The $\mathrm{M}-\mathrm{O}$ frequencies for cobalt, nickel, copper and iron complexes were observed, respectively, at $321 \mathrm{~cm}^{-1}, 330 \mathrm{~cm}^{-1}, 341 \mathrm{~cm}^{-1}$ and $315 \mathrm{~cm}^{-1}$ while M-N frequencies were identified at $411 \mathrm{~cm}^{-1}, 415$ $\mathrm{cm}^{-1}, 411 \mathrm{~cm}^{-1}$ and $409 \mathrm{~cm}^{-1}$, respectively. These results are in agreement with the literature values, being similar to other metal complexes with amino acids. ${ }^{12}$

\section{Thermal analysis}

According to the thermogravimetric data the complexes can be formulated as $\left[\mathrm{M}\left(\mathrm{C}_{6} \mathrm{H}_{10} \mathrm{NO}_{2} \mathrm{~S}\right)_{2}\right](\mathrm{M}=\mathrm{Co}$, $\mathrm{Ni}, \mathrm{Cu}$ or $\mathrm{Fe}$ ). Ligand oxidation in the cobalt, nickel and copper complexes starts at temperatures near $200^{\circ} \mathrm{C}$. For the iron complex, ligand oxidation starts at $135^{\circ} \mathrm{C}$. Residual oxides after thermal treatment of the cobalt, nickel, copper and iron complexes were identified by $\mathrm{X}$ ray diffractometry as $\mathrm{CoO}, \mathrm{NiO}, \mathrm{CuO}$ and $\mathrm{Fe}_{2} \mathrm{O}_{3}$, respectively. ${ }^{15-18}$

Differential thermal analysis of the cobalt(II) complex shows two well-defined exothermic peaks with maxima at $285^{\circ} \mathrm{C}$ and $524^{\circ} \mathrm{C}$ and a very weak one at $373^{\circ} \mathrm{C}$. These effects are assigned to the ligand oxidation of the complex $\left[\mathrm{Co}\left(\mathrm{C}_{6} \mathrm{H}_{10} \mathrm{NO}_{2} \mathrm{~S}\right)_{2}\right]$ in two steps, leading to $\mathrm{CoO}$ as the final product at $950^{\circ} \mathrm{C}$. For $\left[\mathrm{Ni}\left(\mathrm{C}_{6} \mathrm{H}_{10} \mathrm{NO}_{2} \mathrm{~S}\right)_{2}\right]$ three well defined exothermic peaks were observed, with maxima at $296^{\circ} \mathrm{C}$, $415^{\circ} \mathrm{C}$ and $524^{\circ} \mathrm{C}$ with formation of $\mathrm{NiO}$ as the final product of the thermal treatment. For $\left[\mathrm{Cu}\left(\mathrm{C}_{6} \mathrm{H}_{10} \mathrm{NO}_{2} \mathrm{~S}\right)_{2}\right]$ two well-defined exothermic peaks were observed at $211^{\circ} \mathrm{C}$ and $419^{\circ} \mathrm{C}$. As in the case of the cobalt and nickel complexes, these peaks can be assigned to ligand oxidation, leading to the formation of a mixture of $\mathrm{Cu}_{2} \mathrm{OSO}_{4}$ and $\mathrm{CuO}$ at $450^{\circ} \mathrm{C}$. Subsequent mass variation is attributed to $\mathrm{SO}_{2}$ loss, leading to the formation of $\mathrm{CuO}$ as the final product. The $\left[\mathrm{Fe}\left(\mathrm{C}_{6} \mathrm{H}_{10} \mathrm{NO}_{2} \mathrm{~S}\right)_{2}\right]$ complex exhibits two well defined exothermic peaks at 243 and $523^{\circ} \mathrm{C}$, being attributed to ligand oxidation in two steps, with the formation of $\mathrm{Fe}_{2} \mathrm{O}_{3}$.

\section{Magnetic measurements}

Since the experimental value obtained for the magnetic moment of $\mathrm{Co}$ (II) in the cobalt(II) complex is $4.10 \mathrm{BM}$, while the calculated value for an octahedral $\mathrm{d}^{7}$ high spin electronic distribution is $3.87 \mathrm{BM}$, we conclude that $\mathrm{Co}(\mathrm{II})$ in $\left[\mathrm{Co}\left(\mathrm{C}_{6} \mathrm{H}_{10} \mathrm{NO}_{2} \mathrm{~S}\right)_{2}\right]$ is in an octahedral geometry with a high spin configuration. ${ }^{19} \mathrm{Ni}(\mathrm{II})$ in the $\left[\mathrm{Ni}\left(\mathrm{C}_{6} \mathrm{H}_{10} \mathrm{NO}_{2} \mathrm{~S}\right)_{2}\right]$ complex is also in an octahedral geometry. In this case, the experimental value obtained for the magnetic moment for
$\mathrm{Ni}(\mathrm{II})$ is $3.07 \mathrm{BM}$ and the calculated value is $2.83 \mathrm{BM}^{20}$ For $\left[\mathrm{Cu}\left(\mathrm{C}_{6} \mathrm{H}_{10} \mathrm{NO}_{2} \mathrm{~S}\right)_{2}\right]$ the experimental magnetic moment measured is equal to $1.88 \mathrm{BM}$, while the calculated one for a $\mathrm{d}^{9}$ configuration is equal to $1.73 \mathrm{BM} .{ }^{11}$ In all cases the experimental values for the magnetic moment are higher than the calculated ones for the spin only values. This difference between calculated and experimental values is due to the orbital angular momentum. It was not possible to perform magnetical measurements for the iron(II) complex due to iron(II) oxidation at air during sample handling.

\section{Electronic paramagnetic ressonance}

The EPR spectrum of the copper(II) complex in the solid state is characterized by the presence of an isotropic signal centered at $g=2.1273$, which can be assigned to a slightly distorted octahedral geometry due to the JahnTeller effect. Very similar results were also found for $\mathrm{K}_{2} \mathrm{PbCu}\left(\mathrm{NO}_{2}\right)_{6}$, and for other pseudo-octahedral $\mathrm{Cu}$ (II) complexes. ${ }^{11}$

\section{${ }^{57} \mathrm{Fe}$ Mössbauer spectroscopy}

The isomer shift $(\delta)$, quadrupole splitting $(\Delta)$, linewidth $(\Gamma)$ and relative area values for $\left[\mathrm{Fe}\left(\mathrm{C}_{6} \mathrm{H}_{10} \mathrm{NO}_{2} \mathrm{~S}\right)_{2}\right]$ are shown in Table 2.

Table 2. Mössbauer parameters for $\left[\mathrm{Fe}\left(\mathrm{C}_{6} \mathrm{H}_{10} \mathrm{NO}_{2} \mathrm{~S}\right)_{2}\right]$

\begin{tabular}{lcccc}
\hline $\begin{array}{l}\text { oxidation } \\
\text { state }\end{array}$ & $\delta\left(\mathrm{mms}^{-1}\right)$ & $\Delta\left(\mathrm{mms}^{-1}\right)$ & $\Gamma\left(\mathrm{mms}^{-1}\right)$ & $\begin{array}{c}\text { Relative } \\
\text { area }(\%)\end{array}$ \\
\hline $\mathrm{Fe}^{2+}$ & $1.12(1)$ & 2.31 & $0.26(1)$ & 26 \\
$\mathrm{Fe}^{2+}$ & $1.11(1)$ & 2.51 & $0.26(1)$ & 39 \\
$\mathrm{Fe}^{3+}$ & $0.33(1)$ & 0.97 & $0.44(1)$ & 25 \\
$\mathrm{Fe}^{3+}$ & $0.39(1)$ & 0.46 & $0.30(1)$ & 9 \\
\hline
\end{tabular}

According to the data presented in Table 2, the percentage of $\mathrm{Fe}^{2+}$ in the sample is $65 \%$. The isomer shifts observed of $1.11 \mathrm{mms}^{-1}$ and $1.12 \mathrm{mms}^{-1}$ corresponds to the expected value for octahedral $\mathrm{Fe}^{2+}$ complexes, as it was previously described for the iron(II) cysteine complex, which exhibits a distorted octahedral symmetry with an isomer shift of $1.05 \mathrm{mms}^{-1}$ and a quadrupolar splitting of $3.14 \mathrm{mms}^{-1}$, and also for the recently obtained iron(II) djenkolate complex, which exhibits an isomer shift of 1.09 $\mathrm{mms}^{-1}{ }^{21,22}$ As it was previously reported, the presence of $\mathrm{Fe}^{3+}(34 \%)$ in an octahedral geometry is well characterized by the isomer shifts of $0.33 \mathrm{mms}^{-1}$ and $0.39 \mathrm{mms}^{-1} .^{13}$ The presence of iron(III) complex detected in the Mössbauer spectrum is due to oxidation of iron(II) during sample handling. 


\section{Solubility}

The complexes show poor solubility in water and in the common organic solvents such as hexane, ethanol, chloroform, dichloromethane, ethyl ether and acetone. This behavior is consistent with a polymeric chain, as in the case of S,S'-methylenebis(cysteine) and methionine complexes with $\mathrm{Co}(\mathrm{II}), \mathrm{Ni}$ (II), $\mathrm{Cu}$ (II) and $\mathrm{Fe}(\mathrm{II}){ }^{8,10-13}$

\section{Conclusions}

Based on the chemical and spectroscopic results the following schematic structure of coordination for the complexes is proposed in Figure 2.

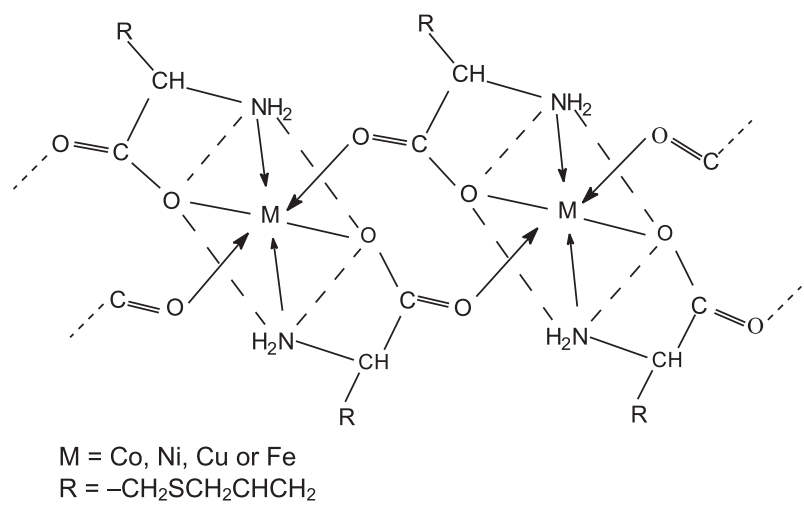

Figure 2. Proposed schematic structures for the $\left[\mathrm{M}\left(\mathrm{C}_{6} \mathrm{H}_{10} \mathrm{NO}_{2} \mathrm{~S}\right)_{2}\right]$ complexes.

According to the proposed structure, the ligand would be coordinated to the metal ions via carboxylate and amino groups. A polymeric octahedral or a pseudo-octahedral arrangement is proposed for the complexes on the basis of the infrared spectra, electronic absorption spectra and magnetic measurements. Mössbauer parameters for the iron complex indicate the presence of iron(II) and iron(III) species both of octahedral geometry. For the iron(II) complex is important to stand out that elemental, thermal and electronic absorption analyses were performed with a freshly prepared sample, while Mössbauer results correspond to a sample which suffered some ageing with partial oxidation of iron(II) to iron(III). Thermal analysis confirms the composition of the complexes. The complexes show poor solubility in water and in common organic solvents, which reinforces the proposition of a polymeric structure.

\section{Acknowledgments}

Authors are grateful to Dra. Paula S. Haddad and Dr. Laudemir C. Varanda for Mössbauer measurements. Authors are also grateful to Dr. Mario S. Schultz for the
EPR spectrum. Financial support: FAPESP (Proc. 03/ 02616-7, 99/04591-4 and 92/3515-3) and CNPq (Brazilian Agencies).

\section{References}

1. Renis, H. E.; Henze, R. E.; Food Res. 1958 23, 45.

2. Suzuki, T.; Sugii, M.; Kakimoto, T.; Tsuboi, N.; Chem. Pharm. Bull. 1961, 9, 251.

3. Dion, M. E.; Agler, M.; John, A.; Nutr. Cancer 1997, $28,1$.

4. Welch, C.; Wuarin, L.; Sidell, N.; Cancer Lett. 1992, 63, 211.

5. Li, G.; Quiao, C. H.; Lin, R. I.; Pinto, J.; Osborne, M. P.; Tiwari, R. K.; Oncol. Rep. 1995, 2, 787.

6. Nagae, S.; Ushijima, M.; Hatono, S.; Imai, J.; Kasuga, S., Matsuura, H.; Itakura, Y.; Higashi, Y.; Planta Med. 1994, 60, 214.

7. Lever, A. B. P.; Inorganic Electronic Spectroscopy, Elsevier Science Publishers: Amsterdam - Oxford - New York - Tokio, 1984.

8. MCauliffe, C. A.; Quagliano, J. V.; Vallarino, L. M.; Inorg. Chem. 1966, 5, 1996.

9. Corbi, P. P.; Melnikov, P.; Massabni, A. C.; J. Alloys Comp. 2000, 308, 153.

10. Corbi, P. P.; Cavicchioli, M.; Melnikov, P.; Massabni, A. C.; Oliveira, L. A. A., Russ. J. Coord. Chem. 2000, 26, 29.

11. Hathaway, B. J.; Billing, D. E.; Coord. Chem. Rev. 1970, 5, 143.

12. Nakamoto, K.; Infrared Spectra of Inorganic and Coordination Compounds, $5^{\text {th }}$ ed. John Wiley: New York, 1997

13. Melnikov, P.; Corbi, P. P.; Aguila, C. D.; Zacharias, M. A.; Cavicchioli, M.; Massabni, A. C.; J. Alloys Comp. 2000, 307, 179.

14. Silverstein, R. M.; Webster F. X.; Spectrometric Identification of Organic Compounds, $6^{\text {th }}$ ed., John Wiley \& Sons: New York, 1998.

15. JCPDS-ICDD Powder Diffraction File $\mathrm{n}^{\circ}$ 9-0402.

16. JCPDS-ICDD Powder Diffraction File $\mathrm{n}^{\circ}$ 22-1189.

17. JCPDS-ICDD Powder Diffraction File $n^{\circ}$ 41-0254.

18. JCPDS-ICDD Powder Diffraction File $n^{\circ} 33-0664$

19. Shriver, D. F.; Atkins, P. W.; Langford, C. H.; Inorganic Chemistry, $2^{\text {nd }}$ ed., Oxford University Press: Oxford, 1994.

20. Oliveira, L. F. C.; Massabni, A. C.; Ecl. Quim. 1985, 10, 53.

21. Murray, K. S.; Newman, P. J.; Aust. J. Chem. 1975, 28, 773.

22. Terzian, G.; Panossian, R.; Benlian, D.; Inorg. Chim. Acta 1981, 54, L153.

Received: May 19, 2004

Published on the web: March 6, 2005

FAPESP helped in meeting the publication costs of this article. 